\title{
Co-Production of Bisphenylpropanoid Amides and Meroterpenes by an Endophytic Penicillium brasilianum Found in the Root Bark of Melia azedarach
}

Taicia P. Fill ${ }^{\mathrm{a}}$, Regina M. Geris dos Santos ${ }^{\mathrm{b}}$, Anderson Barisson ${ }^{\mathrm{c}}$, Edson Rodrigues-Filho ${ }^{\mathrm{a}, *}$, and Antonia Q. L. Souza ${ }^{\mathrm{d}}$

a Departamento de Química, Universidade Federal de São Carlos, CP 676, CEP 13565-905, São Carlos, SP, Brazil. E-mail: edson@dq.ufscar.br

b Instituto de Química, Departamento de Química Orgânica, Universidade Federal da Bahia, CEP 40170-270, Bahia, Brazil

c Laboratório de Bioensaios (FCA) e de Genética (ICB), Universidade Federal do Amazonas, CEP 69077-000, Manaus, Brazil

d Departamento de Química, Universidade Federal do Paraná, CEP 81530-900, Curitiba, Brazil

* Author for correspondence and reprint requests

Z. Naturforsch. 64c, 355-360 (2009); received December 9, 2008/February 9, 2009

A fungus, isolated from the root bark of Melia azedarach (Meliaceae), from which a series of meroterpenes have been reported, was identified as Penicillium brasilianum based on analysis of the ITS region of ribosomal DNA. From a rice culture of this fungus, the known phenylpropanoid amides brasiliamide A and B were obtained together with and a new, slightly modified congener, along with the meroterpenoids preaustinoid A1, preaustinoid B2 and austinolide. The compounds were isolated by the use of combined chromatographic procedures and identified by physical methods, mainly 1D and 2D NMR experiments, with distinction for ${ }^{1} \mathrm{H}\left\{{ }^{15} \mathrm{~N}\right\}$ HMBC applied to brasiliamide A. The amides were tested for their antimicrobial activity and showed only weak inhibitory effects, against a set of pathogenic bacteria.

Key words: Melia azedarach, Penicillium brasilianum, Bisphenylpropanoid, Brasiliamide

\section{Introduction}

During our continuous studies on endophytic microorganisms (Santos et al., 2003), a Penicillium sp. was found associated with Melia azedarach (Meliaceae). In previous works, we reported that this Penicillium sp. is a rich source of interesting secondary metabolites such as insecticidal meroterpenoids, a class of complex metabolites derived from a mixed terpenoid-polyketide biosynthetic pathway, and tremorgenic alkaloids (verruculogen) (Santos et al., 2003; Santos and RodriguesFilho, 2002, 2003a, b, 2004; Fill et al., 2007). Analysis of the ITS region of the ribosomal DNA allowed its identification as $P$. brasilianum. It has been shown now that this fungus produces bisphenylpropanoid amides (brasiliamides 1-5), as already reported in the literature (Fujita et al., 2002; Fujita and Hayashi, 2004). Brasiliamides A (1) and B (2) (Fig. 1) were first identified as secondary metabolites from $P$. brasilianum isolated from soil (Fujita et al., 2002), and, when evalu- ated, these compounds showed convulsive activities against silkworms (Bombyx mori).

From $P$. brasilianum found in $M$. azedarach we obtained two known bisphenylpropanoid $N$ acetylamides, $\mathbf{1}$ and $\mathbf{2}$, and one new congener from the methanolic extract obtained when the fungus was cultivated on sterilized rice for three weeks. We report here the production, isolation and identification of these amides.

\section{Material and Methods}

\section{General experimental procedures}

Optical rotations were measured on a Perkin Elmer 241 polarimeter. UV spectra were obtained in $\mathrm{CH}_{2} \mathrm{Cl}_{2}$ on a Hewlett Packard 8452-A spectrophotometer, and IR spectra were measured with a Bomen MB-102 spectrophotometer using $\mathrm{KBr}$ pellets. Low-resolution ESIMS data were acquired in the negative ion mode, using a QUATTRO-LC instrument (Micromass, Manchester, UK) equipped with an ESI/APCI ion 
<smiles>COc1cc(C/C(=I/NC(C)=O)N(CC(=O)Cc2ccccc2)C(C)=O)cc2c1OCO2</smiles>

Brasiliamide A (1) $\mathrm{C}_{24} \mathrm{H}_{26} \mathrm{~N}_{2} \mathrm{O}_{6}$ 438.1791<smiles>COc1cc(CC2CN(C(C)=O)CC(Cc3ccccc3)N2C(C)=O)cc2c1OCO2</smiles>

Brasiliamide D (4) $\mathrm{C}_{24} \mathrm{H}_{28} \mathrm{~N}_{2} \mathrm{O}_{5}$ 424.1998<smiles>COc1cc(CC2=CN(C(C)=O)CC(Cc3ccccc3)N2C(C)=O)cc2c1OCO2</smiles>

Brasiliamide B (2) $\mathrm{C}_{24} \mathrm{H}_{26} \mathrm{~N}_{2} \mathrm{O}_{5}$ 422.1842<smiles>COc1cc(CC2CNCC(Cc3ccccc3)N2C(C)=O)cc2c1OCO2</smiles>

Brasiliamide E (5) $\mathrm{C}_{22} \mathrm{H}_{26} \mathrm{~N}_{2} \mathrm{O}_{4}$ 382.1893<smiles>COc1cc(/C=C2\CN(C(C)=O)CC(Cc3ccccc3)N2C(C)=O)cc2c1OCO2</smiles>

Brasiliamide C (3) $\mathrm{C}_{24} \mathrm{H}_{26} \mathrm{~N}_{2} \mathrm{O}_{5}$ 422.1842<smiles>COc1cc(CC2=IN(C(C)=O)C(Cc3ccccc3)C(=O)N2O)cc2c1OCO2</smiles>

Brasiliamide $\mathrm{F}(\mathbf{6})$
$\mathrm{C}_{22} \mathrm{H}_{22} \mathrm{~N}_{2} \mathrm{O}_{6}$
410.1478

Fig. 1. Chemical structures of the brasiliamides produced by P. brasilianum.

source. ${ }^{1} \mathrm{H},{ }^{13} \mathrm{C}$ and ${ }^{15} \mathrm{~N}$ NMR experiments were conducted on a BRUKER DRX-400 spectrometer with $\mathrm{CDCl}_{3}$ as the solvent and TMS as the internal standard.

\section{Isolation of the microorganism}

Details on the plant material collection and fungus isolation procedure are given elsewhere (Santos and Rodrigues-Filho, 2002, 2003a) The general procedures adopted followed the methodology described by Petrini et al. (1992). The P brasilianum used in the present work (LaBioMi024) is deposited at the Laboratório de Bioquímica Micromolecular de Microorganismos (LaBioMMi) of the Departamento de Química, Universidade Federal de São Carlos, São Carlos, Brazil.

\section{Rice culture of Penicillium sp. and isolation of} the amides

Fifty Erlenmeyer flasks $(500 \mathrm{ml})$ containing about $90 \mathrm{~g}$ of rice ("Uncle Ben's", Mars, Canada) and $75 \mathrm{ml}$ of distilled water per flask were autoclaved twice at $121^{\circ} \mathrm{C}$ for $40 \mathrm{~min}$. A small disc of the PDA medium from the Petri dish containing mycelium of Penicillium sp. was transferred under sterile conditions to 47 of the 50 Erlenmeyer flasks containing sterilized rice. Three flasks were kept for control purposes. After $20 \mathrm{~d}$ of growth, the water that had accumulated in the flasks was separated by filtration from the fungal biomass. About $150 \mathrm{ml}$ of methanol were added to each flask; the mixture was allowed to stand for $5 \mathrm{~h}$ and filtrated by gravity. The methanol was evaporated under reduced pressure, producing a yellowish residue $(6 \mathrm{~g})$, which was subjected to low-pressure silica gel CC eluted with a hexane to methanol gradient (hexane; hexane/dichloromethane 90:10, 70:30, 50:50, 30:70; dichloromethane; dichloromethane/ methanol 99:1; methanol 100\%). The medium polar fractions eluted with dichloromethane/methanol 95:5 were reiteratively chromatographed on silica gel columns, and the meroterpenoids preaustinoid A1, preaustinoid B2 and austinolide were finally purified by preparative TLC (hexane/ ethyl acetate 1:1). The fraction eluted with dichloromethane/methanol 90:10 gave the brasiliamides $\mathbf{1}, \mathbf{2}$ and $\mathbf{6}$ after further purification by preparative TLC (dichloromethane/ethyl acetate/methanol 7:2:1).

Brasiliamide $A$ (1) : Colourless amorphous powder; m.p. $132-134^{\circ} \mathrm{C} .-[\alpha]_{\mathrm{D}}^{25}-0.45^{\circ}\left(c\right.$ 2.7, $\left.\mathrm{CHCl}_{3}\right)$. - UV: $\lambda_{\max }\left(\mathrm{CH}_{3} \mathrm{OH}\right)=211,233,255(\mathrm{sh}) \mathrm{nm}$. - IR $(\mathrm{KBr}): v_{\max }=3455,3288,2932,2850,1700,1672$, $1636 \mathrm{~cm}^{-1} .-{ }^{1} \mathrm{H}$ NMR (400 MHz, $\mathrm{CDCl}_{3}$, standard 
$\left.\mathrm{SiMe}_{4}\right)$ : see Table I. $-{ }^{13} \mathrm{C}$ NMR $\left(100 \mathrm{MHz}, \mathrm{CDCl}_{3}\right.$, standard $\mathrm{SiMe}_{4}$ ), HSQC and HMBC: see Table I. - ESIMS (daugther ions, $10 \mathrm{eV}$ ): $\mathrm{m} / z=439$ (40) $[\mathrm{M}+\mathrm{H}]^{+}, 380(100), 338$ (30). - ESIMS (daugther ions, $20 \mathrm{eV}): \mathrm{m} / z=437(5)[\mathrm{M}-\mathrm{H}]^{-}, 419(15), 395$ (5), 378 (30), 336 (50), 58 (100).

Brasiliamide $F(\mathbf{6})$ : Colourless amorphous powder; m.p. $119-124^{\circ} \mathrm{C}$. $-\mathrm{UV}\left(\mathrm{CH}_{3} \mathrm{OH}\right): \lambda_{\max }=213$, 276 (sh) nm. - IR (KBr): $v_{\max }=3436,2920,2845$, 1733, 1673, 1644, $1497 \mathrm{~cm}^{-1} .-{ }^{1} \mathrm{H}$ NMR $(400 \mathrm{MHz}$, $\mathrm{CDCl}_{3}$, standard $\mathrm{SiMe}_{4}$ ): see Table I. $-{ }^{13} \mathrm{C}$ NMR $\left(100 \mathrm{MHz}, \mathrm{CDCl}_{3}\right.$, standard $\left.\mathrm{SiMe}_{4}\right)$, HSQC and HMBC: see Table I. - ESIMS (daugther ions, $20 \mathrm{eV}): m / z=409$ (60) [M-H], 394 (30), 379 (5), 367 (100), 352 (35).

\section{Results and Discussion}

Among the numerous fungi collected from organs of M. azedarach (Santos et al., 2003), only one Penicillium sp. was found to be a producer of meroterpenes (Santos et al., 2003; Santos and Rodrigues-Filho, 2002, 2003a, 2003b, 2004), evaluated by liquid chromatography coupled with mass spectrometry (LC/MS) (Santos and RodriguesFilho, 2004). These meroterpenoid compounds show close structure similarities with limonoids, which are endogenous compounds produced by the host plant. Other characteristic secondary metabolites produced by this Penicillium sp. were verruculogen and methyl penicillate (Santos et al., 2003). In the present work, ribosomal DNA analysis was conducted to identify this fungus at species level. A total of 507 base pairs (ITS region) were decoded and compared with the GeneBank database. Two good matches were found with $P$. brasilianum strains CBS 253.55 and RMF 8007, showing an error value of 0.0 (100\% reliability).

A literature survey of secondary metabolites produced by this fungus species showed that it is a producer of bisphenylpropanoid amides, named brasiliamides (Fujita et al., 2002; Fujita and Hayashi, 2004). These amides cause convulsion to silkworms. The phenylpropanoid units in each of these compounds are a methoxypiperonyl cinnamic acid derivative and a modified phenylalanine. Although genes encoding the phenylpropanoid biosynthetic pathway have been found in fungi (Seshine et al., 2005a, 2005b), there is no report on the expression of these genes to produce fungal phenylpropanoid compounds. Thus we were motivated to look for this type of compounds in our strain of $P$. brasilianum.

The fungus was cultivated over sterilized rice, extracted and submitted to a combination of chromatographic procedures which led to the purification of the previously reported meroterpenoids preaustinoid A1, preaustinoid B2 and austinolide (Santos and Rodrigues-Filho, 2003b), and of three compounds with brasiliamide profile, when analyzed by ${ }^{1} \mathrm{H}$ NMR. Only five members of this class of secondary metabolites are known until now (Fujita et al., 2002; Fujita and Hayashi, 2004). All of these compounds contain a phenyl group, recognized in the NMR spectrum by the presence of a $5 \mathrm{H}$ multiplet at ca. $\delta$ 7.15-7.35, and a methoxypiperonyl group which shows two signals for meta coupled hydrogen signals at $\delta$ $6.28(d, J=1.5 \mathrm{~Hz}, \mathrm{H}-5)$ and $6.23(d, J=1.5 \mathrm{~Hz}$, H-9), two AB oxymethylenic hydrogen atoms at $\delta 5.96 / 5.94$, and a methoxy group at $\delta 3.84(s, 3 \mathrm{H}-$ 3"), like observed for brasiliamide A (Fujita et al., 2002) (Table I). Both the methoxypiperonyl and the phenyl groups may be present as benzyl partial structures (I and II, Fig. 2), and this is seen by the two pairs of diastereotopic methylenic hydrogen atoms at ca. $\delta 2.30-4.30$. The atom numbering system adopted so far for brasiliamides is ambiguous (Fujita et al., 2002; Fujita and Hayashi, 2004). In the present work we numbered the atoms considering that the amino acid phenylalanine is a precursor of these brasiliamides.

The electrospray (ESI) mass spectra obtained for the major brasiliamide $\mathbf{1}$ showed prominent
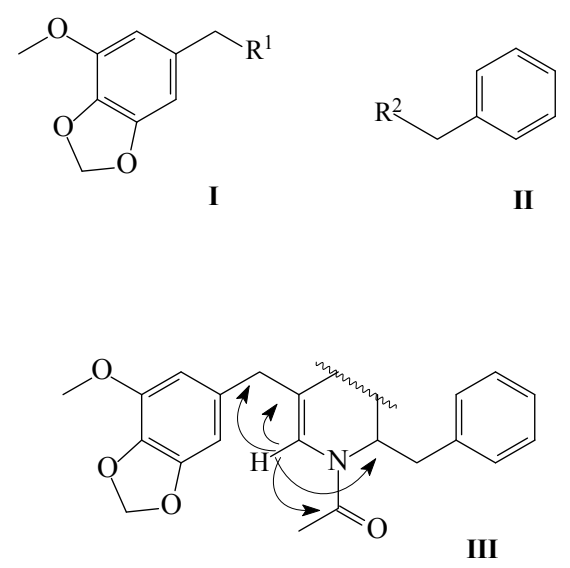

Fig. 2. Partial structures deduced for brasiliamides based on NMR data. 
Table I. NMR spectroscopic data of brasiliamides 1 and $\mathbf{6}\left(\mathrm{CDCl}_{3}, 400 \mathrm{MHz}\right.$ for ${ }^{1} \mathrm{H}$ and $100 \mathrm{MHz}$ for $\left.{ }^{13} \mathrm{C}\right)$.

\begin{tabular}{|c|c|c|c|c|c|c|}
\hline \multirow[t]{2}{*}{ Position } & \multicolumn{3}{|r|}{1} & \multicolumn{3}{|c|}{6} \\
\hline & ${ }^{13} \mathrm{C}$ & ${ }^{1} \mathrm{H}$ & ${ }^{1} \mathrm{H}\left\{{ }^{13} \mathrm{C}\right\}$ and ${ }^{1} \mathrm{H}\left\{{ }^{15} \mathrm{~N}\right\}$ HMBC & ${ }^{13} \mathrm{C}$ & ${ }^{1} \mathrm{H}$ & ${ }^{1} \mathrm{H}\left\{{ }^{13} \mathrm{C}\right\} \mathrm{HMBC}$ \\
\hline 1 & 122.1 & $6.92 d(10.5)$ & $\mathrm{C}-2, \mathrm{C}-3, \mathrm{~N}-10, \mathrm{~N}-11, \mathrm{~N}^{10} \mathrm{COCH}$ & $\mathrm{I}_{3} 113.0$ & 6.15 brs & $\mathrm{C}-1$ '”, C-2, C-2', C-3 \\
\hline 2 & 122.4 & - & - & 121.1 & - & - \\
\hline $3 a$ & 40.1 & $3.30 d(14.5)$ & $\mathrm{C}-1, \mathrm{C}-4, \mathrm{C}-5, \mathrm{C}-9, \mathrm{~N}-11$ & 38.0 & $4.27 \mathrm{brm}$ & - \\
\hline $3 b$ & - & $3.19 d(14.5)$ & $\mathrm{C}-1, \mathrm{C}-4, \mathrm{C}-5, \mathrm{C}-9, \mathrm{~N}-11$ & - & $3.44 d(15.6)$ & C- 1, C-2, C- 4, C-5, C-9 \\
\hline 4 & 131.3 & - & - & 132.1 & - & - \\
\hline 5 & 102.9 & $6.28 d(1.5)$ & C-3, C-6, C-7, C-9 & 102.3 & $6.36 \mathrm{brs}$ & C-3, C-4, C-6, C-7, C-9 \\
\hline 6 & 149.9 & - & - & 148.8 & - & - \\
\hline 7 & 134.4 & - & - & 137.1 & - & - \\
\hline 8 & 143.8 & - & - & 143.4 & - & - \\
\hline 9 & 108.2 & $6.23 d(1.5)$ & C-3, C-5, C-7, C-8 & 108.1 & $6.36 \mathrm{brs}$ & C-3, C-4, C-6, C-7, C-9 \\
\hline 1'a & 56.6 & $4.53 d(17.0)$ & $\mathrm{C}-2, \mathrm{C}-2^{\prime}, \mathrm{N}^{11} \mathrm{COCH}_{3}$ & 166.4 & - & - \\
\hline $1^{\prime} \mathrm{b}$ & - & $3.02 d(17.0)$ & $\mathrm{C}-2, \mathrm{C}-2^{\prime}, \mathrm{N}^{11} \mathrm{C}_{\mathrm{OCH}}$ & - & - & - \\
\hline 2 & 206.9 & - & - & 52.0 & $4.93 \mathrm{brm}$ & n.d. \\
\hline 3’a & 47.8 & $3.82 d(16.0)$ & C-1', C-2', C-4', C-5'/9' & 35.0 & $2.99 d d(11.7,12.0)$ & n.d. \\
\hline $3^{\prime} \mathrm{b}$ & - & $3.74 d(16.0)$ & C-1', C-2', C-4', C-5'/9' & - & $2.50 d(12.0)$ & C-1', C-4', C-5', C-9' \\
\hline 4 & 132.6 & - & - & 133.8 & - & - \\
\hline $5^{\prime} / 9$ ' & 129.4 & $7.18 \mathrm{~m}$ & C-3', C-5', C-7' & 129.2 & $7.15 \mathrm{~m}$ & C-3', C-4', C-5', C-9' \\
\hline $6^{\prime} / 8$ & 128.8 & $7.34 \mathrm{~m}$ & C-4', C-6' & 128.8 & $7.32 \mathrm{~m}$ & - \\
\hline 7 ' & 127.4 & $7.29 \mathrm{~m}$ & $\mathrm{C}-5^{\prime} / 9^{\prime}$ & 126.9 & $7.27 \mathrm{~m}$ & C-3', C-4', C-7' \\
\hline $\mathrm{OCH}_{3}$ & 56.7 & $3.84 s$ & $\mathrm{C}-8$ & 56.7 & $3.87 s$ & C-4' \\
\hline $\mathrm{OCH}_{2} \mathrm{O}$ & 101.4 & $5.96 / 5.94 \mathrm{~m}$ & C-6, C-7 & 101.3 & $5.93 \mathrm{brs}$ & C-5', C-9' \\
\hline $\mathrm{N}^{10} \mathrm{COCH}_{3}$ & 23.1 & $2.10 s$ & $\mathrm{C}-1, \mathrm{~N}^{10} \mathrm{COCH}_{3}, \mathrm{~N}-10$ & 21.5 & $2.23 s$ & C-8 \\
\hline $\mathrm{N}^{10} \mathrm{COCH}_{3}$ & 168.2 & - & - & 169.2 & - & C-6, C-7 \\
\hline $\mathrm{N}^{11} \mathrm{COCH}_{3}$ & 20.0 & $1.87 s$ & $\mathrm{~N}^{11} \mathrm{COCH}_{3}, \mathrm{~N}-11$ & - & - & C-1" \\
\hline $\mathrm{N}^{11} \mathrm{COCH}_{3}$ & 170.7 & - & - & - & - & - \\
\hline $\mathrm{N}^{10}-\mathrm{H}$ & - & $9.63 d(10.5)$ & $\mathrm{C}-2, \mathrm{~N}^{10} \mathrm{COCH}_{3}$ & - & - & - \\
\hline
\end{tabular}

Coupling constants $(\mathrm{Hz})$ in parentheses. n.d., Not detected.

peaks at $m / z 439$, when positive ions were scanned, and $m / z 437$ in the negative ion mode, confirming a molecular weight (MW) of 438 amu. By counting the ${ }^{13} \mathrm{C}$ NMR signals and using the ${ }^{1} \mathrm{H}$ NMR peak area, along with the MS data, the molecular formula $\mathrm{C}_{24} \mathrm{H}_{26} \mathrm{~N}_{2} \mathrm{O}_{6}$ is suggested for this fungal metabolite. This molecular formula is the same as obtained for brasiliamide A (Fujita et al., 2002). All of the physical data reported for this compound are coincident with ours, confirming its identification. Further confirmation of the brasiliamide A structure was given by analysis of ${ }^{15} \mathrm{~N}$ NMR data (Table I). Thus, $\left.{ }^{1} \mathrm{H}_{\{}{ }^{15} \mathrm{~N}\right\}$ HSQC showed correlation of the amide hydrogen signal at $\delta 9.63$ $(d, J=10.5 \mathrm{~Hz})$ with a nitrogen nucleus $(\mathrm{N}-10)$; in the ${ }^{1} \mathrm{H}\left\{{ }^{15} \mathrm{~N}\right\}$ HMBC spectrum there were correlations between $\mathrm{H}-1$ with $\mathrm{N}-10$ and $\mathrm{N}-11, \mathrm{H}-3 \mathrm{a}$ and $\mathrm{H}-3 \mathrm{~b}$ with $\mathrm{N}-11$, and $\mathrm{H}-1$ 'a and $\mathrm{H}-1$ 'b with $\mathrm{N}-11$. Brasiliamide $\mathrm{B}\left(\mathrm{C}_{24} \mathrm{H}_{26} \mathrm{~N}_{2} \mathrm{O}_{5}, 422 \mathrm{amu}\right)$ was identified in the same way as for brasiliamide $\mathrm{A}$, but without the use of ${ }^{15} \mathrm{~N}$ NMR spectroscopy due the small amount of the compound isolated.

The above identified brasiliamides are di- $N$ acetylated compounds containing a methoxypiperonyl and a benzyl group. A brasiliamide that contains only one $3 \mathrm{H}$ singlet for an $N$-acetyl group in the ${ }^{1} \mathrm{H}$ NMR spectrum was also obtained from $P$. brasilianum extracts. This brasiliamide monoacetate was analyzed by MS and showed $[\mathrm{M}-\mathrm{H}]^{-}$produced by ESI at $\mathrm{m} / z$ 409, indicating a MW of $410 \mathrm{amu}$ and differing from brasiliamide E $\left(\mathrm{C}_{22} \mathrm{H}_{26} \mathrm{~N}_{2} \mathrm{O}_{4}, 382 \mathrm{amu}\right)$ (Fujita and Hayashi, 2004), the only brasiliamide monoacetate known so far. The presence of the methoxypiperonyl $(\delta$ 6.36, brs, H-5 and H-9; $\delta$ 5.93, brs, 2H-4"; $\delta 3.87$, $s, 3 \mathrm{H}-3$ ") $)$ and the benzyl ( $\delta 2.99, d d, \mathrm{H}-3$ 'a; $\delta 2.50$, $d, \mathrm{H}-3$ 'b; $\delta$ 7.15-7.27, $m, \mathrm{H}-5$ ' to 9') groups was evident in the ${ }^{1} \mathrm{H}$ NMR spectrum of this unknown brasiliamide. The two signals at $\delta 4.93\left(\mathrm{H}-2^{\prime}\right)$ and $\delta 4.27(\mathrm{H}-3 \mathrm{a})$ were observed as broad lines, prob- 
ably due to a strong influence of vicinal quadrupolar nitrogen atoms, or due to the presence of rotamers like demonstrated for brasiliamide A (Fujita and Hayashi, 2004). The partial structure III (Fig. 2) was confirmed for this unknown amide based on the establishment of the connectivities between the methoxypiperonyl (I, Fig. 2) and benzyl (II, Fig. 2) groups assigned by the 2D HMBC and NOE measurements. Thus, upon irradiation, $\mathrm{H}-5$ and $\mathrm{H}-9$ (both at $\delta$ 6.36) showed NOE with H-1 $(\delta 6.15), 3 \mathrm{H}-2$ " $(\delta$ 2.23), the diastereotopic benzylic hydrogen atoms at $\delta 4.27(\mathrm{H}-$ $3 \mathrm{a})$ and $\delta 3.44(\mathrm{H}-3 \mathrm{~b})$ and the methoxy hydrogen atoms at $\delta 3.87$ (3H-3"). NOE was also observed with $\mathrm{H}-5 / \mathrm{H}-9, \mathrm{H}-3 \mathrm{~b}$ and $3 \mathrm{H}-2$ " ( $N$-acetyl) when $\mathrm{H}-1$ ( $\delta$ 6.15) was irradiated. The NMR signal of $\mathrm{H}-1$, which is a doublet in brasiliamide $\mathrm{A}$, was detected as a singlet $(\delta 6.15)$, indicating, along with the NOE between $\mathrm{H}-3 / 3 \mathrm{H}-2$ ", the presence of an $N, N$-disubstituted $N$-acetylamide. H-1 is HMBCcorrelated with C-2 ( $\delta$ 121.1), C-3 ( $\delta$ 38.0), C-2' $(\delta$ 52.0) and also with C-1" $(\delta$ 169.2). Thus, the partial structure containing the methoxypiperonyl group (III, Fig. 2) seems to be the same as the one present in brasiliamide B. Actually, this unknown amide shows very similar NMR characteristics as reported for brasiliamide B [8], with some broad NMR peaks when the spectrum is measured at ca. $20^{\circ} \mathrm{C}$, probably due to the presence of rotamers. The mass spectral data of this unknown amide $\left(\mathrm{m} / \mathrm{z} 409[\mathrm{M}-\mathrm{H}]^{-}\right.$, obtained by negative ion ESIMS), along with the above discussed NMR data are compatible with the molecular formula $\mathrm{C}_{22} \mathrm{H}_{22} \mathrm{~N}_{2} \mathrm{O}_{6}(410 \mathrm{amu})$. The above identified partial structure (III, Fig. 2) corresponds to the formula $\mathrm{C}_{21} \mathrm{H}_{21} \mathrm{NO}_{4}$, which means that the

Chittari P., Jadhev V. R., Ganesh K. N., and Rajappa S. (1998), Synthesis and metal complexation of chiral 3-mono- or 3,3-bis-allyl-2-hydroxypyrrolopyrazine1,4-diones. J. Chem. Soc. Perkin Trans. 1, 1319-1324.

Essemberg M. (2001), Prospects for strengthening plant defenses through phytoalexin engineering. Physiol. Mol. Plant. Pathol. 59, 71-81.

Ferrer J. L., Austin M. B., Stewart C., and Noel J. P. (2008), Structure and function of enzymes involved in the biosynthesis of phenylpropanoids. Plant Physiol. Biochem. 46, 356-370.

Fill T. P., Santos R. M. G., and Rodrigues-Filho E. (2007), Four additional meroterpenes produced by Penicillium sp. found in association with Melia azedarach. Possible biosynthetic intermediates to austin. Z. Naturforsch. 62b, 1035-1044. fragment $\mathrm{CHNO}_{2}$ needs to be added to III to complete the unknown structure. The ${ }^{13} \mathrm{C}$ NMR spectrum contains a shielded carbonyl signal at $\delta 166.4$, which is compatible with the presence of an $N$-hydroxylamide group, when compared with model compounds (Hirsch et al., 1989; Chittari et al., 1998). Thus, this brasiliamide was identified and named brasiliamide $\mathrm{F}$.

The antimicrobial properties of brasiliamide A, the major amide obtained, were tested against a set of pathogenic bacteria, but 1 showed only a weak bacteriostatic effect to Bacillus subtilis with a minimal inhibitory concentration (MIC) of $250 \mu \mathrm{g} / \mathrm{ml}$.

Apparently, these brasiliamides are biosynthesized from two phenylalanine units. In plants, the bisphenylpropanoid pathway produces lignans and other cinnamic acid derivatives (Ferrer et. al., 2008). This process begins with the action of the enzyme phenylalanine ammonia lyase (PAL) to produce cinnamic acid and cinnamic acid-derived compounds, and is frequently associated with plant defense mechanisms against invading microorganisms (Essenberg, 2001). This biosynthetic route is not so far found in microorganisms. Thus, $P$. brasilianum deserves a careful study to check the production and expression of the enzyme PAL.

\section{Acknowledgement}

The authors are grateful to Fundação de Amparo à Pesquisa do Estado de São Paulo (FAPESP), Conselho Nacional de Desenvolvimento Científico e Tecnológico (CNPq), and Coordenação de Aperfeiçoamento de Pessoal de Ensino Superior (CAPES) for financial support and research fellowships.

Fujita T. and Hayashi H. (2004), New brasiliamide congeners, brasiliamides C, D and E, from Penicillium brasilianum Batista JV-379. Biosci. Biotechnol. Biochem. 68, 820-826.

Fujita T., Makishima D., Akiyama K., and Hayashi H. (2002), New convulsive compounds, brasiliamides A and B, from Penicillium brasilianum Batista JV-379. Biosci. Biotechnol. Biochem. 66, 1697-1705.

Hirsch S., Miroz A., McCarthy P., and Kashman Y. (1989), Etzionin, a new antifungal metabolite from a red sea tunicate. Tetrahedron Lett. 30, 4291-4294.

Petrini O., Sieber T. N., Toti L., and Viret O. (1992), Ecology, metabolite production and substrate utilization in endophytic fungi. Nat. Toxins 1, 185-196. 
Santos R. M. G. and Rodrigues-Filho E. (2002), Meroterpenes from Penicillium sp. found in association with Melia azedarach. Phytochemistry 61, 907-912.

Santos R. M. G. and Rodrigues-Filho E. (2003a), Structures of meroterpenes produced by Penicillium sp., an endophytic fungus found associated with Melia azedarach. J. Braz. Chem. Soc. 14, 722-727.

Santos R. M. G. and Rodrigues-Filho E. (2003b), Further meroterpenes produced by Penicillium sp., an endophyte obtained from Melia azedarach. Z. Naturforsch. 58c, $663-669$.

Santos R. M. G. and Rodrigues-Filho E. (2004), Análise de padrões de meroterpenos por cromatografia líquida acoplada a espectrometria de massas LC/ESI-MS/ MS. LabCiencia Not. Tec. Lab. 3, 12-14.
Santos R. M. G., Rodrigues-Filho E., Rocha W. C., and Teixeira M. F. S. (2003), Endophytic fungi from $M e-$ lia azedarach. World J. Microbiol. Biotechnol. 19, $767-770$.

Seshime Y., Juvvadi P. R., Fuji I., and Kitamoto K. (2005a), Discovery of a novel superfamily of type III polyketide synthases in Aspergillus oryzae. Biochem. Biophys. Res. Commun. 331, 253-260.

Seshime Y., Juvvadi P. R., Fuji I., and Kitamoto K. (2005b), Genomic evidences for the existence of a phenylpropanoid metabolic pathway in Aspergillus oryzae. Biochem. Biophys. Res. Commun. 337, $747-751$. 